\title{
Effect of increasing the colloidal calcium phosphate of milk on the texture and microstructure of yogurt
}

\author{
T. Ozcan, ${ }^{*} \dagger$ D. Horne, ${ }^{*}$ and J. A. Lucey ${ }^{*} \ddagger^{1}$ \\ *Department of Food Science, University of Wisconsin-Madison, Madison 53706-1565 \\ †Department of Food Engineering, Uludag University, 16059 Gorukle, Bursa, Turkey \\ ¥Wisconsin Center for Dairy Research, Madison 53706-1565
}

\section{ABSTRACT}

The effect of increasing the colloidal calcium phosphate (CCP) content on the physical, rheological, and microstructural properties of yogurt was investigated. The CCP content of heated $\left(85^{\circ} \mathrm{C}\right.$ for $\left.30 \mathrm{~min}\right)$ milk was increased by increasing the $\mathrm{pH}$ by the addition of alkali $(\mathrm{NaOH})$. Alkalized milk was dialyzed against pasteurized skim milk at approximately $4^{\circ} \mathrm{C}$ for $72 \mathrm{~h}$ to attempt to restore the original $\mathrm{pH}$ and soluble $\mathrm{Ca}$ content. By adjustment of the milk to $\mathrm{pH}$ values $7.45,8.84,10.06$, and 10.73 , the CCP content was increased to approximately $107,116,123$, and $128 \%$, respectively, relative to the concentration in heated milk. During fermentation of milk, the storage modulus $\left(\mathrm{G}^{\prime}\right)$ and loss tangent values of yogurts were measured using dynamic oscillatory rheology. Large deformation rheological properties were also measured. The microstructure of yogurt was observed using fluorescence microscopy, and whey separation was determined. Acid-base titration was used to evaluate changes in the CCP content in milk. Total Ca and casein-bound $\mathrm{Ca}$ increased with an increase in the $\mathrm{pH}$ value of alkalization. During acidification, elevated buffering occurred in milk between $\mathrm{pH}$ values 6.7 to 5.2 with an increase in the $\mathrm{pH}$ of alkalization. When acidified milk was titrated with alkali, elevated buffering occurred in milk between $\mathrm{pH}$ values 5.6 to 6.4 with an increase in the $\mathrm{pH}$ of alkalization. The high residual $\mathrm{pH}$ of milk after dialysis could be responsible for the decreased contents of soluble Ca in these milks. The $\mathrm{pH}$ of gelation was higher in all dialyzed samples compared with the heated control milk, and the gelation $\mathrm{pH}$ was higher with an increase in CCP content. The sample with highest CCP content (128\%) exhibited gelation at very high $\mathrm{pH}(6.3)$, which could be due to alkaliinduced $\mathrm{CN}$ micellar disruption. The $\mathrm{G}^{\prime}$ values at $\mathrm{pH}$ 4.6 were similar in gels with CCP levels up to $116 \%$; at higher $\mathrm{CCP}$ levels, the $\mathrm{G}^{\prime}$ values at $\mathrm{pH} 4.6$ greatly

Received October 14, 2010.

Accepted August 7, 2011.

${ }^{1}$ Corresponding author: jalucey@facstaff.wisc.edu decreased. Loss tangent values at $\mathrm{pH} 5.1$ were similar in all samples except in gels with a CCP level of $128 \%$. For dialyzed milk, the whey separation levels were similar in gels made from milk with up to $107 \%$ CCP but increased at higher CCP levels. Microstructure of yogurt gels made from milk with 100 to $107 \%$ CCP was similar but very large clusters were observed in gels made from milk with higher CCP levels. By dialyzing heated milk against pasteurized milk, we may have retained some heat-induced $\mathrm{Ca}$ phosphate on micelles that normally dissolves on cooling because, during dialysis, pasteurized milk provided soluble $\mathrm{Ca}$ ions to the heated milk system. Yogurt texture was significantly affected by increasing the casein-bound $\mathrm{Ca}$ (and total $\mathrm{Ca}$ ) content of milk as well as by the alkalization procedure involved in that approach.

Key words: yogurt, colloidal calcium phosphate, rheology, microstructure

\section{INTRODUCTION}

Yogurt is a semisolid dairy product made by fermentation of milk with Streptococcus thermophilus and Lactobacillus delbrueckii ssp. bulgaricus cultures. Aggregation and gelation of $\mathrm{CN}$ occurs due to the reduction in charge repulsion with the decrease in milk $\mathrm{pH}$ (Lucey and Singh, 1997). Within the CN micelles, CN molecules are held together primarily by hydrophobic interactions and (insoluble or casein-bound) colloidal calcium phosphate (CCP) crosslinks (Horne, 1998; Fox and Brodkorb, 2008). These CCP crosslinks are dissolved with a decrease in milk pH (Pyne and McGann, 1960) and caseins are liberated into the serum phase (Dalgleish and Law, 1989). The extent of liberation of caseins depends on the temperature at acidification; at $30^{\circ} \mathrm{C}$, a decrease in $\mathrm{pH}$ causes virtually no liberation of protein (Dalgleish and Law, 1989). Thus, during yogurt fermentation, which is performed at temperatures $>30^{\circ} \mathrm{C}$, no dissociation of CN likely occurs.

Many factors influence the texture and physical properties of yogurt gels, including heat treatment (Dannenberg and Kessler, 1988; van Vliet and Keetels, 
1995), incubation temperature (Lee and Lucey, 2004), rate of acidification (Horne, 2003; Anema, 2008), and fortification with milk proteins (Sodini et al., 2004). Ozcan-Yilsay et al. (2007) used a different approach to alter yogurt texture. They added low concentrations of trisodium citrate to milk to reduce the level of CCP cross-linking between CN. Higher gel stiffness and decreased whey separation were observed in yogurt when low levels of TSC were used. Ozcan-Yilsay et al. (2007) suggested that low levels of CCP removal facilitated greater rearrangement and molecular mobility of the micelle structure, which may have helped increase the formation of crosslinks between strands in yogurt gel networks. In contrast, when most of the CCP was dissolved, complete micelle disruption occurred, which caused the formation of very weak yogurt gels.

McGann and Pyne (1960) developed a method to increase the CCP content of milk. The $\mathrm{pH}$ value of cold $\left(\sim 0^{\circ} \mathrm{C}\right)$ milk is increased by the addition of base $(\mathrm{NaOH})$. The increased $\mathrm{pH}$ alters the Ca equilibrium and a shift occurs from soluble to insoluble (caseinbound) Ca. Dialysis of the $\mathrm{pH}$-adjusted milk against bulk milk restores the soluble Ca content but the CCP content remains high and the overall $\mathrm{Ca}$ content is increased (McGann and Pyne, 1960). This method has been used in a variety of studies to examine the effect of the CCP concentration on milk properties such as heat stability (Fox and Hoynes, 1975; Singh and Fox, 1987). Recently, Anema (2009) used the method of McGann and Pyne (1960) to alter the CCP content of milk and studied the effect of CCP on acid gels made by the addition of glucono- $\delta$-lactone (GDL). Anema (2009) reported that increasing the CCP content of milk resulted in a slight increase in the gelation $\mathrm{pH}$ of GDL-induced gels but had no consistent effect on storage modulus $\left(\mathbf{G}^{\prime}\right)$ values at $\mathrm{pH}$ 4.6. The properties of model acid gels made with GDL have been reported to differ greatly from yogurt gels made by bacterial fermentation (Lucey et al., 1998b), probably because of the markedly different rate of acidifications with these 2 approaches (some proteolysis may also occur in fermented milks). Anema (2009) altered the CCP content of milk before high heat treatment $\left(80^{\circ} \mathrm{C}\right.$ for $\left.30 \mathrm{~min}\right)$, but it is known that the CCP content of milk influences heat stability (Singh and Fox, 1987) so we heated the milk before altering the CCP content. At very high temperatures (i.e., $>110^{\circ} \mathrm{C}$ ), $\mathrm{CCP}$ can be involved in cross-linking of proteins, resulting in the formation of protein aggregates (Singh, 1994). We are not aware of any published study on the properties of yogurts made from milk with an elevated CCP content. The present study was performed to investigate the effect of increasing the CCP content of milk on yogurt gelation.

\section{MATERIALS AND METHODS}

\section{Materials}

Low-heat skim milk powder with a whey undenatured protein nitrogen index of $6.60 \mathrm{mg} / \mathrm{g}$ (Bradley et al., 1992) was supplied by Dairy Farmers of America (Fresno, CA). Yogurt starter culture (Streptococcus thermophilus and Lactobacillus delbrueckii ssp. bulgaricus, YC-087) was obtained from Chr. Hansen Inc. (Milwaukee, WI). Fresh pasteurized cow's milk was obtained from the UW-Madison Food Science Dairy Plant.

\section{Milk Preparation and Dialysis}

To increase the CCP content of milk, we followed the method described by McGann and Pyne (1960). Reconstituted skim milk (10.7\% wt/vol) was preheated at $85^{\circ} \mathrm{C}$ for $30 \mathrm{~min}$ in a thermostatically controlled waterbath and then cooled rapidly with ice water to 0 to $2^{\circ} \mathrm{C}$. Immediately after cooling, $2 \mathrm{~N} \mathrm{NaOH}$ was added to milk to reach concentrations of $0,0.5,1,1.5$, and $2 \%$ (vol/vol) by the slow addition of alkali with continuous stirring at approximately $0^{\circ} \mathrm{C}$. Milks were stirred for 1 $\mathrm{h}$ and the $\mathrm{pH}$ was then recorded at approximately $0^{\circ} \mathrm{C}$.

The $\mathrm{pH}$ values of the samples containing $0,0.5,1$, 1.5 , and $2 \%$ (vol/vol) $\mathrm{NaOH}$ were $6.68,7.45,8.84$, 10.06 , and 10.73 , respectively. The resulting mixtures were dialyzed using a dialysis membrane with a molecular weight cut-off of 6 to $8 \mathrm{kDa}$. One liter of each treated milk sample was dialyzed against $10 \mathrm{~L}$ of fresh pasteurized skim milk with regular changes of milk. Total dialysis time was $72 \mathrm{~h}$, with around 10 changes of milk during this period. The bags were left to reach equilibrium at 0 to $5^{\circ} \mathrm{C}$ and stirred for $72 \mathrm{~h}$. By the end of this dialysis period, the $\mathrm{pH}$ values of all milks had decreased. At the end of the dialysis procedure, the $\mathrm{pH}$ values of the samples containing $0,0.5,1,1.5$, and $2 \%$ $\mathrm{NaOH}(\mathrm{vol} / \mathrm{vol})$ were $6.69,6.75,6.86,6.92$, and 6.93 , respectively.

Some milk samples were used for chemical analysis; $0.02 \%$ (wt/wt) sodium azide was added to prevent bacterial growth in these samples. For yogurt fermentation, starter culture was prepared according to the method described by Ozcan et al. (2008). Before the addition of culture, milk was rewarmed at $60^{\circ} \mathrm{C}$ for $30 \mathrm{~min}$ to try to restore $\mathrm{CN}$ or milk salt changes induced by the cold storage used for the dialysis procedure. Milk were cooled to $42^{\circ} \mathrm{C}$ and inoculated with $2 \%$ (wt/wt) working culture. The $\mathrm{pH}$ was recorded every 5 min during fermentation as described by Ozcan et al. (2008). The initial acidification rate (i.e., for a $1.0 \mathrm{pH}$ change from the original starting $\mathrm{pH}$ ) was determined from the $\mathrm{pH}$ 
profiles and expressed as $\mathrm{pH}$ milliunits per minute (mU/min; Lee and Lucey, 2004).

\section{Acid-Base Buffering Properties}

Buffering curves of milks were determined by the acid-base titration method described by Lucey et al. (1993b). The area between the acid and base titration curves was used to estimate the CCP content of milk (Lucey et al., 1993b, 1996). The area under the base titration curve from $\mathrm{pH} 4.2$ to the original milk $\mathrm{pH}$ was subtracted from the area under the acid titration curve from the $\mathrm{pH}$ of the original milk to $\mathrm{pH}$ 4.2. Buffering areas for the treated samples were compared with the heated control sample, which was set as 100\% (Table 1 ). We assumed that changes in the buffering capacity as a result of alkalization were due to alterations in the CCP content (i.e., the alkalization procedure did not influence buffering from protein side chains).

\section{Ultrafiltration and Ca Determinations}

A Prep/Scale-TFF membrane (Millipore, Billerica, MA), which was made from regenerated cellulose and had a molecular weight cut-off of $10 \mathrm{kDa}$, was used to obtain UF permeates of milks. The total Ca concentration of milk and soluble Ca contents of UF permeate were determined using inductively coupled plasma-optical emission spectrometer (Vista-MPX Simultaneous ICP-OES, Varian Inc., Palo Alto, CA). The wavelength of plasma emission used to measure the Ca content was 317.9 nm (Park, 2000). Casein-bound Ca was calculated using the following equation (White and Davies, 1958):

$$
\text { Casein-bound } \mathrm{Ca}=\text { total } \mathrm{Ca}-\mathrm{Ca} \text { in UF permeate. }
$$

\section{Yogurt Properties}

Yogurt gel formation was determined by dynamic low amplitude oscillatory rheometry (Paar Physica UDS 200 controlled stress rheometer, Physica Messtechnik GmbH, Stuttgart, Germany) as described by Ozcan et al. (2008). Whey separation values of yogurts were determined using the method described by Lucey et al. (1998a). The fluorescence microscopy method described by Choi et al. (2007) was followed to examine the microstructure of yogurt gels.

\section{Statistical Analysis}

Statistical analysis was conducted by ANOVA using the statistical software SAS (version 9.1, SAS Institute Inc., Cary, NC). Experiments were replicated at least 3 times. Fisher's least significant difference test was

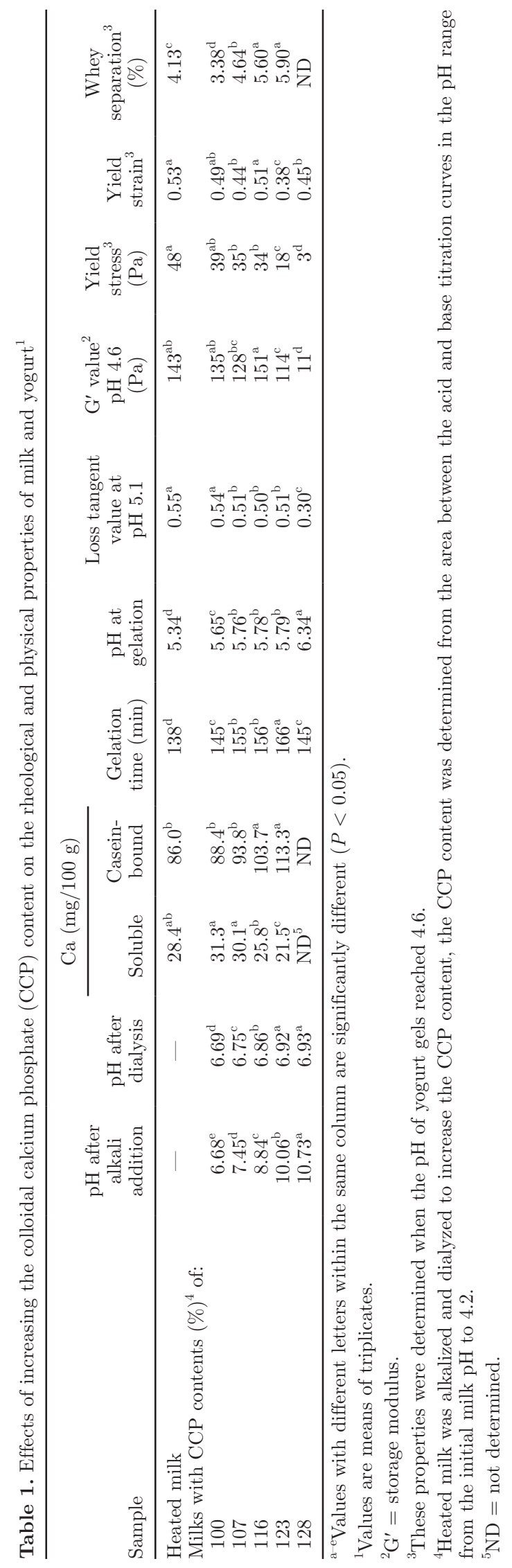


carried out to evaluate differences in treatment means at a significance level of $P<0.05$.

\section{RESULTS}

\section{Acid-Base Buffering Properties}

The acid-base buffering properties of milks are shown in Figure 1. All milk samples exhibited a buffering peak at around $\mathrm{pH} 5.0$ during acid titration, which was due to the solubilization of CCP (Figure 1a; Lucey et al., 1993b). Higher buffering was observed between $\mathrm{pH}$ values 6.7 to 5.2 in milk with an increase in the $\mathrm{pH}$ of alkalization. The buffering observed during the titration of acidified milks with base is shown in Figure 1b. During the back-titration of milk with base, a buffering peak was observed at around $\mathrm{pH} 6.0$ due to formation of insoluble Ca phosphate (Lucey et al., 1993b). Greater buffering was observed between $\mathrm{pH}$ values 5.5 to 6.4 in milk with an increase in the $\mathrm{pH}$ of alkalization. During the titration of acidified milk with base, the buffering peak was shifted to slightly lower $\mathrm{pH}$ values with an increase in the $\mathrm{pH}$ of alkalization.

\section{Soluble and Casein-Bound $\mathrm{Ca}$}

The effect of alkalization of milk followed by dialysis on the soluble and casein-bound Ca content is shown in Table 1. Casein-bound Ca increased with an increase in the $\mathrm{pH}$ of alkalization. The soluble Ca content of the dialyzed sample without alkalization was slightly (but not significantly) higher than that of the heated control milk. Milks with a CCP content of $116 \%$ exhibited a decrease in soluble Ca content compared with the dialyzed control or milk with CCP content of $107 \%$. Increasing the CCP content of milk to $123 \%$ resulted in a further significant decrease in the soluble Ca content. Milks with a CCP content of $128 \%$ were difficult to ultrafilter as these samples became translucent with some visual precipitation. We did not determine the casein-bound Ca for the milk with a CCP content of $128 \%$. Milks with CCP contents of 116 and $123 \%$ had significantly elevated casein-bound $\mathrm{Ca}$ contents compared with the dialyzed control or the milk with a CCP content of $107 \%$. Total Ca levels also exhibited a significant increase with an increase in the $\mathrm{pH}$ of alkalization.

\section{pH Profiles}

The $\mathrm{pH}$ profiles during acidification with $2 \%$ (wt/ wt) starter culture at $42^{\circ} \mathrm{C}$ are shown in Figure 2. The $\mathrm{pH}$ profile of the dialyzed sample without alkalization exhibited a slower rate of $\mathrm{pH}$ change from approximately 100 min after culture addition until the end of fermentation compared with the heated control milk (not dialyzed). For the remainder of the fermentation process, the slopes of the $\mathrm{pH}$ profiles appeared similar. The initial rate of acidification was 7.2, 6.4, 5.8, 5.9, 6.0, and $5.1 \mathrm{mU} / \mathrm{min}$ for the heated control milk (not dialyzed) and samples with CCP contents of 100, 107, 116, 123 , and $128 \%$, respectively. Because the heated milk not dialyzed and heated milk dialyzed (100\% CCP) had similar buffering profiles (Figure 1), this difference in initial acid development was related to an alteration in bacterial fermentation. An increase was observed in the initial $\mathrm{pH}$ value of dialyzed milks compared with the heated control milk, which could have contributed to slower bacterial fermentation. During the prolonged dialysis procedure, some change to minor milk constituents may have occurred that contributed to the slower bacterial fermentation of the dialyzed sample without alkalization (100\% CCP) compared with the control milk. The $\mathrm{pH}$ values of milks at a fermentation time of 150 min increased in the following order: 128\% $\mathrm{CCP}>123 \% \mathrm{CCP}=116 \% \mathrm{CCP}>107 \% \mathrm{CCP}>100 \%$ $\mathrm{CCP}>$ heated control milk. This trend agreed with the increased buffering in samples with an increase in the CCP content (Figure 1). The time to reach $\mathrm{pH} 4.6$ increased as follows: $116 \% \mathrm{CCP}=123 \% \mathrm{CCP}=128 \%$ CCP $>107 \%$ CCP $>100 \%$ CCP $>$ heated control milk.

\section{Rheological Properties}

The effects of increasing the CCP content on the rheological and physical properties of milk and yogurt are summarized in Table 1. All dialyzed samples had longer gelation times than the heated control milk even though the dialyzed samples had a higher gelation $\mathrm{pH}$ than the heated control milk. For the dialyzed samples, gelation time increased with an increase in the $\mathrm{pH}$ of alkalization until samples containing $128 \%$ CCP when the gelation time decreased again. Samples containing 107,116 , and $123 \% \mathrm{CCP}$ had similar $\mathrm{pH}$ values at gelation and the $\mathrm{pH}$ value at gelation was higher than the dialyzed control milk. The $\mathrm{pH}$ of gelation for the sample containing $128 \%$ CCP was very high (6.3).

The effects of increasing the CCP content of milk on the $\mathrm{G}^{\prime}$ and loss tangent (LT) values of yogurt as a function of $\mathrm{pH}$ are shown in Figure 3. The heated control milk gelled at low $\mathrm{pH}$ values $(\sim 5.34)$ and the $\mathrm{G}^{\prime}$ values were lower than that of the other samples until around $\mathrm{pH}$ 4.7, when they increased sharply (Figure 3a). After gelation, the $\mathrm{G}^{\prime}$ values for the samples containing 107 and $116 \%$ CCP were higher than those of samples containing 100 and $123 \% \mathrm{CCP}$. The sample containing $128 \%$ CCP exhibited an unusual $\mathrm{G}^{\prime}$ profile; although apparent gelation occurred at a high $\mathrm{pH}$ value, no substantial increase in the $G^{\prime}$ values was observed during 


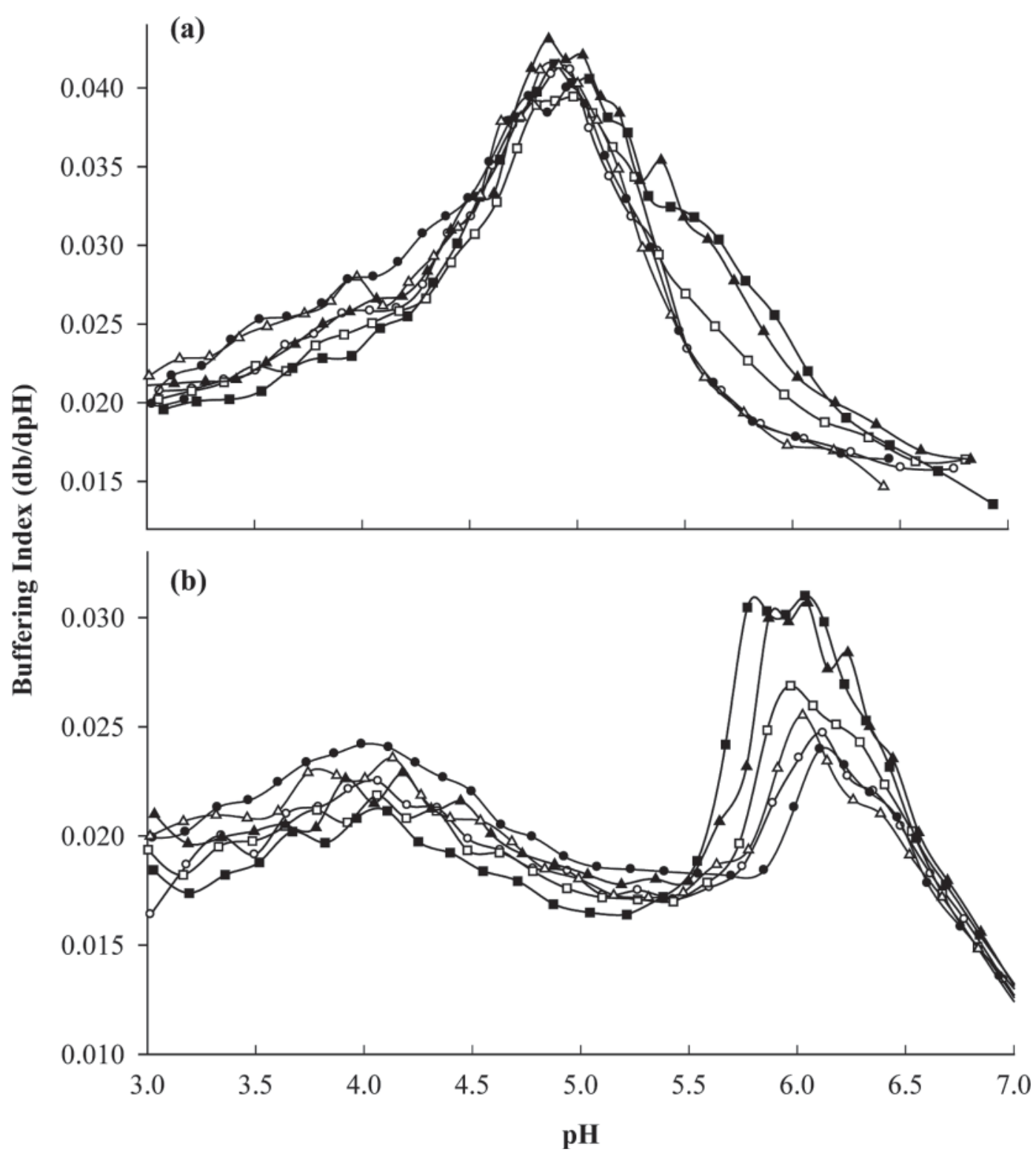

Figure 1. Acid-base buffering curves of milks: (a) titration of milk from initial pH to pH 3.0 with $0.5 \mathrm{~N} \mathrm{HCl}$, and (b) back-titration of acidified milk from $\mathrm{pH} 3.0$ to $\mathrm{pH} 9.0$ with $0.5 \mathrm{~N} \mathrm{NaOH}$. Heated $\left(85^{\circ} \mathrm{C}\right.$ for $\left.30 \mathrm{~min}\right)$ milk $(\triangle)$ and dialyzed milk containing $100 \%(\bullet), 107 \%(\bigcirc), 116 \%$ $(\square), 123 \%(\mathbf{\Lambda})$, and $128 \%$ ( $)$ colloidal calcium phosphate compared with the heated milk.

fermentation and the $\mathrm{G}^{\prime}$ values at $\mathrm{pH} 4.6$ were very low $(\sim 11 \mathrm{~Pa})$.

The LT profiles for yogurt gels are shown in Figure 3b. Apart from the gel made from milk containing $128 \%$ CCP, all samples exhibited a maximum in LT during acidification. The $\mathrm{pH}$ value of the LT maximum in the heated control milk sample was slightly lower compared with that of the dialyzed samples. The LT values for yogurt made from milk containing $128 \% \mathrm{CCP}$ decreased to $<0.5$ at $\mathrm{pH}$ values $>6.2$, in agreement with the very high gelation $\mathrm{pH}$ of this sample (Table 1 ). During the remainder of the fermentation process, the
LT values decreased slowly for the yogurt made from milk containing $128 \%$ CCP.

The yield stress values of yogurt gels decreased with an increase in the $\mathrm{pH}$ of alkalization with a sharp reduction in yield stress values observed in samples containing more than $116 \%$ CCP (Table 1). No consistent trends were observed for the yield strain values of gels made from the heated control or dialyzed samples.

\section{Whey Separation and Microstructure}

The whey separation levels of gels made from the dialyzed sample without alkalization were lower than 


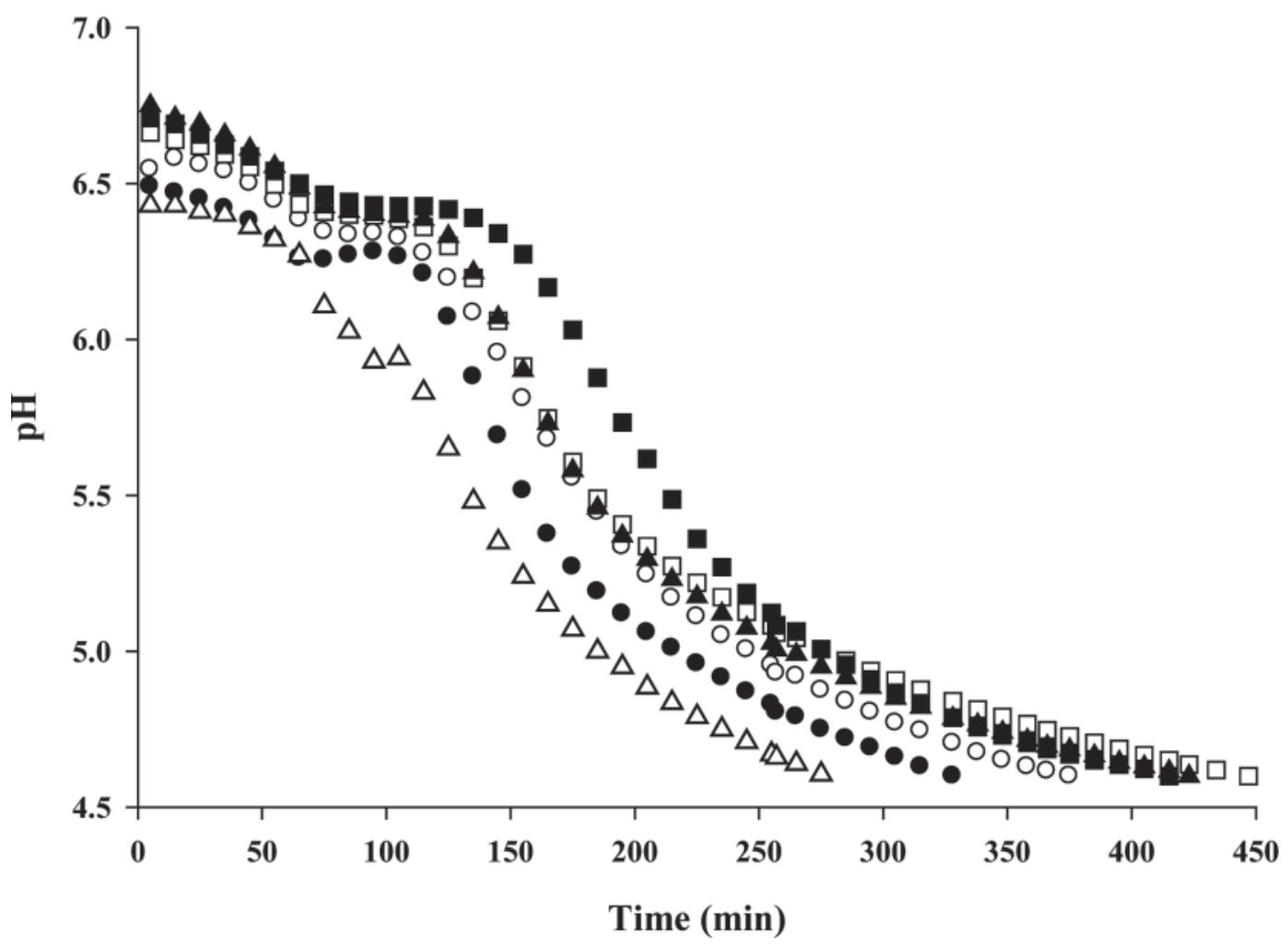

Figure 2. $\mathrm{pH}$ profiles as function of time for yogurts made with $2 \%$ (wt/wt) starter culture at $42^{\circ} \mathrm{C}$ from heated $\left(85^{\circ} \mathrm{C}\right.$ for $\left.30 \mathrm{~min}\right) \mathrm{milk}(\Delta)$

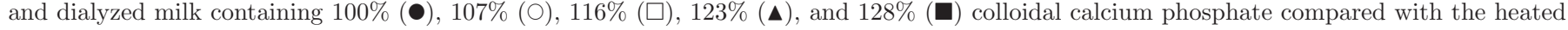
milk.

that of the heated control milk. Whey separation levels in yogurt gels increased with an increase in the $\mathrm{pH}$ of alkalization, and thus with an increase in the CCP level. Weak gels were formed from milk containing $128 \%$ CCP and no whey separation could be measured.

The microstructures of yogurt samples are shown in Figure 4. Similar types of microstructures were observed in gels made from heated milk (Figure 4a) and those made from dialyzed milk containing $100 \%$ CCP (Figure 4b). The gels containing 107\% (Figure 4c) and $116 \%$ CCP (Figure 4d) exhibited larger clusters than the heated milk or $100 \%$ CCP sample. The network in yogurts made from heated milk exhibited small clusters $(<5 \mu \mathrm{m})$ with extensive branching. Yogurts made from milk containing $123 \%$ CCP exhibited very large, dense (many greater than $50 \mu \mathrm{m}$ ) protein clusters (Figure $4 \mathrm{e})$. Large pores $(>20 \mu \mathrm{m})$ could also be observed in this network. Yogurts made from milk containing 128\% CCP did not exhibit a characteristic cross-linked network but instead very large protein agglomerates could be observed (Figure 4f).

\section{DISCUSSION}

In our alkalization-dialysis procedure, milks were subjected to increasing $\mathrm{pH}$ and an elevation in casein- bound $\mathrm{Ca}$ (and increased total Ca content). This procedure altered both milk $\mathrm{pH}$ and mineral equilibria, which greatly affected the properties of $\mathrm{CN}$ micelles and the yogurt gels made from these treated milks.

The addition of alkali to milk (without dialysis against untreated milk) results in a decrease in soluble $\mathrm{Ca}$ and inorganic phosphate (van Dijk, 1992; Vaia et al., 2006). Vaia et al. (2006) reported that adjustment of milk to pH 9 and 10 decreased the soluble Ca levels to approximately 20 and $3 \%$, respectively, compared with the soluble Ca levels in untreated milk. The alkalizationdialysis procedure has been used previously to increase the CCP content of milk (McGann and Pyne, 1960; Fox and Hoynes, 1975; Singh and Fox, 1987; Anema, 2009). In all previous studies, this procedure was applied to either raw or low-heat-treated milk, whereas we used severely heated milk $\left(85^{\circ} \mathrm{C}\right.$ for $\left.30 \mathrm{~min}\right)$. Heat treatment of milk results in an increase in casein-bound $\mathrm{Ca}$ and a concomitant decrease in soluble Ca (Walstra and Jenness, 1984; de la Fuente, 1998); these changes are reversed upon cooling (Pierre and Brulé, 1981; Pouliot et al., 1989). Dialysis of heated milk that was not alkalized (100\% dialyzed sample) against low-heat-treated milk helped to maintain a high level of casein-bound $\mathrm{Ca}$ (Table 1) because the low-heat-treated milk provided 

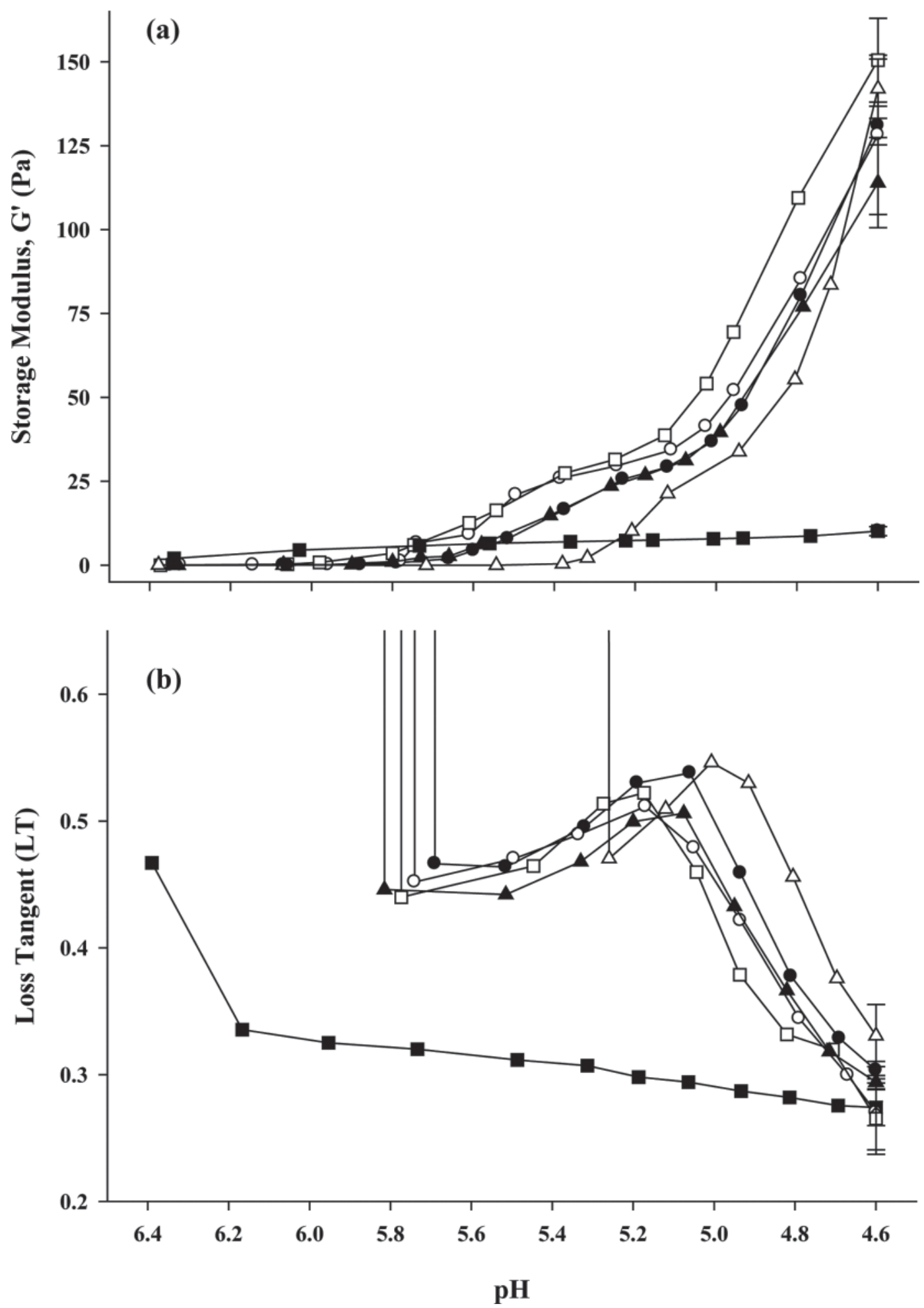

Figure 3. (a) Storage modulus $\left(\mathrm{G}^{\prime}\right)$ and (b) loss tangent (LT) as function of $\mathrm{pH}$ for yogurts made from heated $\left(85^{\circ} \mathrm{C}\right.$ for $\left.30 \mathrm{~min}\right) \mathrm{milk}(\Delta)$ and dialyzed milk containing $100 \%(\bullet), 107 \%(\bigcirc), 116 \%(\square), 123 \%(\boldsymbol{\Delta})$, and $128 \%(\boldsymbol{\square})$ colloidal calcium phosphate compared with the heated milk. Yogurts were made at $42^{\circ} \mathrm{C}$ using $2 \%$ (wt/wt) starter culture. 

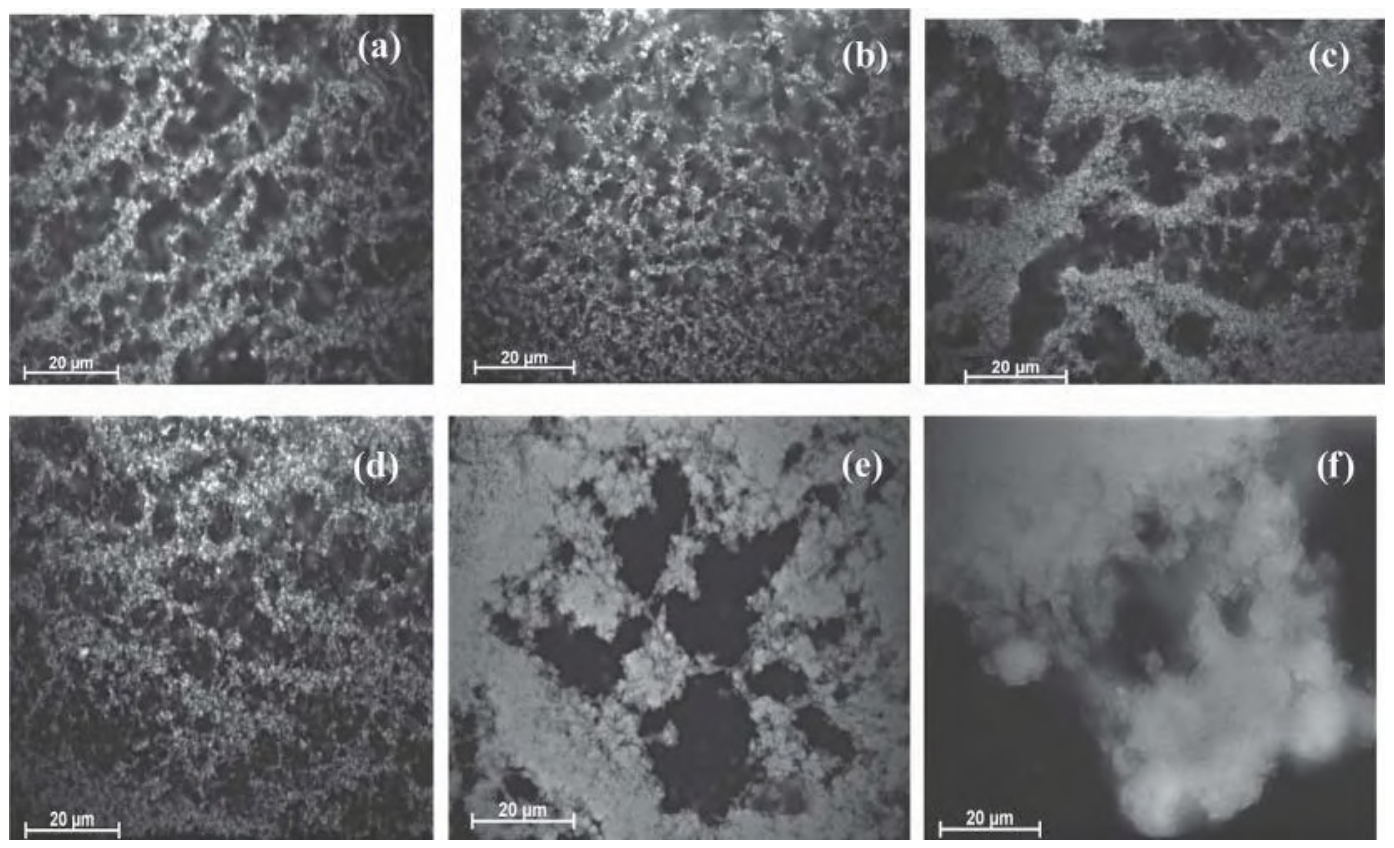

Figure 4. Microstructure of yogurt gels made from heated $\left(85^{\circ} \mathrm{C}\right.$ for 30 min) milk (a) and dialyzed milk containing $100 \%$ (b), $107 \%$ (c), $116 \%$ (d), $123 \%$ (e), and $128 \%$ (f) colloidal calcium phosphate compared with the heated milk. Yogurts were made at $42^{\circ} \mathrm{C}$ using $2 \%$ (wt/wt) starter culture. The protein matrix is white and pores are dark; scale bar $=20 \mu \mathrm{m}$.

soluble Ca during dialysis and decreased the tendency of the heated milk to dissolve its heat-induced CCP. Heated milk was dialyzed immediately after cooling. A similar type of principle is involved in the alkalizationdialysis procedure of McGann and Pyne (1960), except that alkalization (instead of heat treatment) is used to increase the casein-bound $\mathrm{Ca}$ level and dialysis against a milk with a higher soluble Ca level helps restore the soluble Ca level while maintaining the elevated CCP content caused by the alkalization step.

When milk was alkalized to very high $\mathrm{pH}$ values, extensive $(72 \mathrm{~h})$ dialysis was not sufficient to completely restore the original milk $\mathrm{pH}$ value. It could be that the additional $(\mathrm{Ca})$ phosphate in milk may be increasing the "natural" $\mathrm{pH}$ of milk. Exhaustive dialysis for $72 \mathrm{~h}$ with up to 10 changes in milk used for dialysis should have been ample time to attain equilibrium. We did not prolong the dialysis time any further due to concerns about possible proteolysis or cold aging affects that could negatively influence yogurt gelation.

Heat treatment of milk creates heat-induced Ca phosphate, which exhibits similar $\mathrm{pH}$ solubilization behavior compared with the original CCP, unless milk is subjected to severe heating conditions; for example, $120^{\circ} \mathrm{C}$ for $10 \mathrm{~min}$ (Lucey et al., 1993a). Vaia et al. (2006) noted that the nature of the increase in caseinbound Ca caused by alkalization of milk was not known but several options existed: forming insoluble (caseinbound) Ca phosphate and becoming part of nanoclu- sters, which would have to grow in size or number, or binding of ionic $\mathrm{Ca}$ to phosphoserine residues that were not involved in stabilizing nanoclusters. We believe that alkalization resulted in an increase in insoluble Ca phosphate content because we observed an increase in the buffering area between the initial $\mathrm{pH}$ of treated milk and $\mathrm{pH} 4.2$ (Figure 1), which is indicative of an increased concentration of insoluble Ca phosphate (Lucey et al., 1993b, 1996). The acid-base buffering profiles of CCP-enriched milk (Figure 1) appeared generally similar to those observed previously for milk (Lucey et al., 1993b). The CCP-enriched milks created by the alkalization procedure did exhibit some minor differences in buffering behavior, including higher buffering during acidification at $\mathrm{pH}$ values 6.7 to 5.2 compared with that of heated milk. Because alkalization also resulted in an increase in the total $\mathrm{Ca}$ content in milk, it is likely that the $\mathrm{pH}$ solubility of $\mathrm{CCP}$ would be modified as well (which could affect the buffering properties). From our buffering profiles, we believe that alkalization produces CCP that is mostly similar to the native $\mathrm{CCP}$ in milk. It is possible that alkalization induced a change in the type of CCP in milk but different forms of CCP have unique buffering behaviors (Upreti et al., 2006) and we observed only a minor modification to the buffering profiles.

Anema (2009) adjusted the CCP content of unheated milk by acidification/alkalization followed by dialysis against the original unheated milk. After alteration of 
the CCP content, milks were heated and then acidified with GDL. In our study, we first heated the milk before adjusting the CCP content, because adjustment of the CCP content is known to greatly alter the heat stability of milk (Singh and Fox, 1987). Anema (2009) also varied the GDL levels to obtain similar overall acidification times in samples, whereas we added a constant level of starter culture to all milks. Anema (2009) observed only a slight increase $(<0.1 \mathrm{pH}$ unit) in the gelation $\mathrm{pH}$ when the CCP content of milk was increased to $115 \%$. It is possible that the larger change in gelation $\mathrm{pH}$ obtained in our CCP-enriched milk, compared with that of Anema (2009), could be due to the use of heated milk for alkalization-dialysis and the different method of acidification in our study, which was by fermentation of lactose by starter culture. We observed that the gelation $\mathrm{pH}$ increased in alkalized-dialyzed milks, but these milks also had longer gelation times probably because of their high buffering (Figure 1). Addition of Ca to milk has been reported to increase the hydrophobicity of micelles (Philippe et al., 2003) and decrease the zeta potential (Dalgleish, 1984; Philippe et al., 2003), which could help to increase the gelation $\mathrm{pH}$.

We did not observe any significant effect on $\mathrm{G}^{\prime}$ values at $\mathrm{pH} 4.6$ when the CCP content was increased, at least up to $116 \%$ (Table 1). Anema (2009) also reported that elevating the CCP content of milk by $115 \%$ had little effect on the $\mathrm{G}^{\prime}$ values at $\mathrm{pH} 4.6$ for GDL-induced gels. Ozcan-Yilsay et al. (2007) suggested that low levels of CCP removal facilitated greater rearrangement of the micelle structure, which helped to increase the formation of crosslinks between strands in yogurt gel networks and produced gels with higher $\mathrm{G}^{\prime}$ values at $\mathrm{pH}$ 4.6. In our study, the additional CCP did not result in a decrease in the $\mathrm{G}^{\prime}$ values at $\mathrm{pH} 4.6$, possibly because of the high gelation $\mathrm{pH}$ observed for these samples compared with that of the heated control milk.

Removal of CCP from CN micelles results in acid gels with higher LT at pH 5.1 (Ozcan-Yilsay et al., 2007; Anema, 2009; Famelart et al., 2009). The higher $\mathrm{LT}$ values reflect the greater mobility of $\mathrm{CN}$ in the network due to the loss of CCP crosslinks. We observed significantly lower $\mathrm{LT}$ values at a $\mathrm{pH}$ of approximately 5.1 with an increase in the CCP content compared with gels made from the heated control milk (Table 1). Anema (2009) reported that for GDL-induced gels, the LT values from the gelation point until around $\mathrm{pH}$ 5.1 were lower for the samples containing $115 \%$ CCP compared with gels made with $100 \%$ CCP.

It is not clear how milk can be enriched with additional CCP compared with the native $\mathrm{CN}$ micelles. Several studies have indicated that when $\mathrm{Ca}$ is added to milk some of the added Ca becomes associated with CN micelles, presumably as CCP (Brule and Fauquant,
1981; Gastaldi et al., 1994; Philippe et al., 2003). It is also not clear where the additional CCP is in the micelles. Does it form new nanoclusters or larger nanoclusters?

We cannot have a fixed size and functionality for the nanoclusters in native $\mathrm{CN}$ micelles, as suggested by McMahon and Oommen (2008), because this would imply the creation of more (new) nanoclusters and require, for the same reason, more (new) phosphoserine clusters and more (new) caseins in the alkalized milk. However, we cannot have additional caseins because additional casein does not pass the dialysis barrier. We propose that when the $\mathrm{pH}$ is increased, the serine phosphates become more negatively charged and less favorably inclined to associate with the Ca phosphate, which has 2 outcomes. First, the micelle tends to dissociate (becomes less turbid) and this tendency increases the higher the $\mathrm{pH}$ value of the milk (especially at $\mathrm{pH}>9$; Odagiri and Nickerson, 1965; Thompson and Farrell, 1973; Vaia et al., 2006; Huppertz et al., 2008).The second outcome of alkalization is that Ca phosphate tends to precipitate at high $\mathrm{pH}$ values. If this treated milk is dialyzed against a milk of normal $\mathrm{pH}$, the $\mathrm{pH}$ is brought back down and the $\mathrm{Ca}$ binding activity of the serine phosphates are restored. However, if the $\mathrm{pH}$ decrease is slow, the Ca phosphate nanoclusters may grow and thus more CCP is incorporated into the CN micelle. What does this do for the properties of the micelle? It is likely that the incorporation will take time, as will reassembly of the micelle following the (partial) dissociation on increasing the $\mathrm{pH}$ value. The re-formation of $\mathrm{CN}$ micelles after alkali-induced dissociation has been studied and it appears that these micelles largely resemble native micelles (Huppertz et al., 2008).

At the highest CCP level (128\%), unusual gelation behavior was observed, including very high gelation $\mathrm{pH}$ values, weak gels, and an agglomerated, poorly crosslinked yogurt gel network. To attain such a high CCP level, milk had to be adjusted to $\mathrm{pH}$ 10.7. Beeby and coworkers (Beeby and Kumetat, 1959; Beeby and Lee, 1959) reported that viscosity greatly increased when milk was adjusted to $\mathrm{pH}$ values around 11. McGann and Pyne (1960) also noted a large increase in viscosity when the CCP of milk was increased by $>120 \%$. Hemar et al. (2000) observed that milk could undergo alkalineinduced gelation at $\mathrm{pH} 12$. Vaia et al. (2006) proposed that alkaline-induced disruption of $\mathrm{CN}$ micelles was not only related to charge but that increasing the milk $\mathrm{pH}$ improves the solvent quality for the caseins, thereby leading to the disruption of $\mathrm{CN}$ micelles into their constituent nanoclusters. It appeared that extensive dissociation of micelles occurred at very high $\mathrm{pH}$ values because the samples were visually translucent. The micelle system may remain destabilized and partially 
aggregated even after dialysis, and when the $\mathrm{pH}$ is subsequently lowered during fermentation the samples with high CCP levels gelled at a very high $\mathrm{pH}$ value (Table 1). Ozcan-Yilsay et al. (2007) reported that complete disruption of $\mathrm{CN}$ micelles resulted in the formation of very weak yogurt gels from this treated milk.

\section{CONCLUSIONS}

Alkalization of heated $\left(85^{\circ} \mathrm{C}\right.$ for $\left.30 \mathrm{~min}\right)$ milk and dialysis against pasteurized skim milk resulted in an increase in the concentrations of casein-bound and total Ca. One possible explanation for this result could be the growth of CCP nanoclusters. With the increase in milk $\mathrm{pH}$, serine phosphate groups become more negatively charged, which could weaken their interaction with the $\mathrm{CCP}$ nanoclusters. The high $\mathrm{pH}$ favors the precipitation of additional CCP. Dialysis of alkalized milk should restore the binding activity of the serine phosphates and this could allow for growth of the existing nanoclusters. The $\mathrm{pH}$ of gelation was higher in all dialyzed samples compared with that of the heated control milk. By dialyzing heated milk against pasteurized milk, we could have retained some heat-induced Ca phosphate on micelles that normally dissolves on cooling, because the pasteurized milk provided soluble $\mathrm{Ca}$ ions to the heated milk system, thereby reducing the driving force to reverse this heat-induced shift in the Ca equilibrium. Increasing the CCP (and total Ca) content of milk did not greatly affect the $\mathrm{G}^{\prime}$ values at $\mathrm{pH}$ 4.6, LT values, or gel microstructure until the CCP content exceeded $107 \%$. Alkalization of milk to high $\mathrm{pH}$ values is known to cause dissociation of micelles. When milks were alkalized to very high $\mathrm{pH}$ values (10.7) before dialysis, the gels formed during yogurt fermentation were very weak and the gelation $\mathrm{pH}$ was very high. To generate high CCP levels in heated milk required the use of high alkalization $\mathrm{pH}$ values, which negatively affected yogurt gelation properties.

\section{ACKNOWLEDGMENTS}

This work was supported by The Commission of Scientific Research Projects of Uludag University (Bursa, Turkey; project number: YDP (Z)-2010/6) and University of Wisconsin-Madison.

\section{REFERENCES}

Anema, S. G. 2008. Effect of temperature and rate of acidification on the rheological properties of acid skim milk gels. J. Food Proc. Preserv. 32:1016-1033.

Anema, S. G. 2009. Role of colloidal calcium phosphate in the acid gelation properties of heated skim milk. Food Chem. 114:161-167.
Beeby, R., and K. Kumetat. 1959. Viscosity changes in concentrated skim-milk treated with alkali, urea and calcium complexing agents. I. The importance of casein micelle. J. Dairy Res. 26:248-257.

Beeby, R., and J. W. Lee. 1959. Viscosity changes in concentrated milk treated with alkali, urea and calcium-complexing agents. II. The influence of concentration, temperature and rate of shear. J. Dairy Res. 26:258-264.

Bradley, R. L., E. Arnold, D. M. Barbano, R. G. Semerad, D. E. Smith, and B. K. Vines. 1992. Chemical and physical methods. Pages 433-531 in Standard Methods for the Examination of Dairy Products. R. T. Marshall, ed. 16th ed. American Public Health Association, Washington, DC.

Brule, G., and J. Fauquant. 1981. Mineral balance in skim-milk and milk retentate: Effect of physicochemical characteristics of the aqueous phase. J. Dairy Res. 48:91-97.

Choi, J., D. S. Horne, and J. A. Lucey. 2007. Effect of insoluble calcium concentration on rennet coagulation properties of milk. J. Dairy Sci. 90:2612-2623.

Dalgleish, D. G. 1984. Measurement of electrophoretic mobilities and zeta-potentials of particles from milk using laser Doppler electrophoresis. J. Dairy Res. 51:425-438.

Dalgleish, D. G., and A. J. R. Law. 1989. pH induced dissociation of bovine casein micelles. II. Mineral solubilization and its relation to casein release. J. Dairy Res. 56:727-735.

Dannenberg, F., and H. G. Kessler. 1988. Effect of denaturation of $\beta$-lactoglobulin on texture properties of set-style nonfat yoghurt. 1. Syneresis. Milchwissenschaft 43:700-704.

de la Fuente, M. A. 1998. Changes in the mineral balance of milk submitted to technological treatments. Trends Food Sci. Technol. 9:281-288

Famelart, M.-H., G. Gauvin, D. Paquet, and G. Brule. 2009. Acid gelation of colloidal calcium phosphate-depleted preheated milk. J. Dairy Sci. Technol. 89:335-348.

Fox, P. F., and A. Brodkorb. 2008. The casein micelle: Historical aspects, current concepts and significance. Int. Dairy J. 18:677-684.

Fox, P. F., and M. C. T. Hoynes. 1975. Heat stability of milk: Influence of colloidal calcium phosphate and $\beta$-lactoglobulin. J. Dairy Res. 42:427-435.

Gastaldi, E., O. Pellegrini, A. Lagaude, and B. Tarodo de al Fuente. 1994. Functions of added calcium in acid milk coagulation. J. Food Sci. 59:310-312., 320.

Hemar, Y., A. J. R. Law, D. S. Horne, and J. Leaver. 2000. Rheological investigations of alkaline-induced gelation of skimmed milk and reconstituted skimmed milk concentrates. Food Hydrocoll. 14:197-201.

Horne, D. S. 1998. Casein interactions: Casting light on the black boxes, the structure in dairy products. Int. Dairy J. 8:171-177.

Horne, D. S. 2003. Casein micelles as hard spheres: Limitations of the model in acidified gel formation. Colloids Surf. A Physicochem. Eng. Asp. 213:255-263.

Huppertz, T., B. Vaia, and M. A. Smiddy. 2008. Reformation of casein particles from alkaline-disrupted casein micelles. J. Dairy Res. $75: 44-47$.

Lee, W. J., and J. A. Lucey. 2004. Structure and physical properties of yogurt gels: Effect of inoculation rate and incubation temperature. J. Dairy Sci. 87:3153-3164.

Lucey, J. A., C. Gorry, and P. F. Fox. 1993a. Acid-base buffering properties of heated milk. Milchwissenschaft 48:438-441.

Lucey, J. A., C. Gorry, B. O'Kennedy, M. Kalab, R. Tan-Kinita, and P. F. Fox. 1996. Effect of acidification and neutralization of milk on some properties of casein micelles. Int. Dairy J. 6:257-272.

Lucey, J. A., B. Hauth, C. Gorry, and P. F. Fox. 1993b. The acid-base buffering properties of milk. Milchwissenschaft 48:268-272.

Lucey, J. A., P. A. Munro, and H. Singh. 1998a. Whey separation in acid skim milk gels made with glucono- $\delta$-lactone: Effects of heat treatment and gelation temperature. J. Texture Stud. 29:413-426.

Lucey, J. A., and H. Singh. 1997. Formation and physical properties of acid milk gels: A review. Food Res. Int. 30:529-542.

Lucey, J. A., M. Tamehana, H. Singh, and P. A. Munro. 1998b. A comparison of the formation, rheological properties and microstructure 
of acid skim milk gels made with a bacterial culture or glucono- $\delta$ lactone. Food Res. Int. 31:147-155.

McGann, T. C. A., and G. T. Pyne. 1960. The colloidal phosphate of milk. III. Nature of its association with casein. J. Dairy Res. $27: 403-417$.

McMahon, D. J., and B. S. Oommen. 2008. Supramolecular structure of the casein micelle. J. Dairy Sci. 91:1709-1721.

Odagiri, S., and T. A. Nickerson. 1965. Micellar changes in skimmilk treated with alkali or acid. J. Dairy Sci. 48:1157-1160.

Ozcan, T., J. A. Lucey, and D. Horne. 2008. Effect of tetrasodium pyrophosphate on the physicochemical properties of yogurt gels. J. Dairy Sci. 91:4492-4500.

Ozcan-Yilsay, T., W. J. Lee, D. Horne, and J. A. Lucey. 2007. Effect of trisodium citrate on rheological and physical properties and microstructure of yogurt. J. Dairy Sci. 90:1644-1652.

Park, Y. W. 2000. Comparison of mineral and cholesterol composition of different commercial goat milk products manufactured in USA. Small Rumin. Res. 37:115-124.

Philippe, M., F. Gaucheron, Y. Le Great, F. Michel, and A. Garem. 2003. Physicochemical characterization of calcium-supplemented skim milk. Lait 83:45-59.

Pierre, A., and G. Brulé. 1981. Mineral and protein equilibria between the colloidal and soluble phase of milk at low temperature. J. Dairy Res. 48:417-428.

Pouliot, Y., M. Boulet, and P. Paquin. 1989. Observations on the heatinduced salt balance changes in milk. II. Reversibility on cooling. J. Dairy Res. 56:193-199.

Pyne, G. T., and T. C. A. McGann. 1960. The colloidal phosphate of milk. 2. Influence of citrate. J. Dairy Res. 27:9-17.

Singh, H. 1994. Crosslinking of milk proteins on heating concentrated milk at $120^{\circ} \mathrm{C}$. Int. Dairy J. 4:477-489.
Singh, H., and P. F. Fox. 1987. Heat stability of milk: Influence of colloidal and soluble salts and protein modification on the $\mathrm{pH}$-dependent dissociation of micellar к-casein. J. Dairy Res. 54:523-534.

Sodini, I., F. Remeuf, S. Haddad, and G. Corrieu. 2004. The relative effect of milk base, starter, and process on yogurt texture: A review. Crit. Rev. Food Sci. Nutr. 44:113-137.

Thompson, M. P., and H. M. Farrell. 1973. The casein micelle-The forces contributing to its integrity. Neth. Milk Dairy J. 27:220239.

Upreti, P., P. Buhlmann, and L. E. Metzger. 2006. Influence of calcium and phosphorus, lactose, and salt-to-moisture ratio on Cheddar cheese quality: $\mathrm{pH}$ buffering properties of cheese. J. Dairy Sci. 89:938-950.

Vaia, B., M. A. Smiddy, A. L. Kelly, and T. Huppertz. 2006. Solventmediated disruption of bovine casein micelles at alkaline $\mathrm{pH}$. J. Agric. Food Chem. 54:8288-8293.

van Dijk, H. J. M. 1992. The properties of casein micelles. 6. Behaviour above $\mathrm{pH} \mathrm{9,} \mathrm{and} \mathrm{implications} \mathrm{for} \mathrm{the} \mathrm{micelle} \mathrm{model.} \mathrm{Neth.}$ Milk Dairy J. 46:101-113.

van Vliet, T., and C. J. A. M. Keetels. 1995. Effect of preheating milk on the structure of acidified milk gels. Neth. Milk Dairy J. 49:27-35.

Walstra, P., and R. Jenness. 1984. Dairy Chemistry and Physics. John Wiley \& Sons Inc., New York, NY.

White, J. C. D., and D. T. Davies. 1958. The relation between the chemical composition of milk and the stability of the caseinate complex. I. General introduction, description of samples, methods and chemical composition of samples. J. Dairy Res. 25:236-255. 